\title{
Juridical Settlement of Land Procurement on Imposed Lands Outside the Determination of Location (Case Study of Malang-Pandaan Toll Road Development)
}

\author{
Erfan Setianas, Prof.Dr.Suhariningsih. S.H.,S.U., Dr Imam Kuswahyono. S.H.,M.Hum \\ Master of Law Study Program \\ Postgraduate Faculty of Law Universitas Brawijaya \\ Jl. MT. Haryono 169 Malang 65145
}

\begin{abstract}
The purpose of writing this article is to examine the juridical settlement of land acquisition on the affected land outside the location determination, why the affected land is outside the location determination at the land development for the construction of the Pandaan-Malang toll road road in Madyopuro Village, Subdistrict District, yet unsolved. The study method uses an empirical legal approach/socio-legal research. This research was carried out by means of an observation process at an institution related to the construction of the Malang-Pandaan Road Toll Road, especially in the Malang City area and an interview with respondents or sources related to the problem under study, namely the Government Instances as a whole related to land management for toll road development in Malang City as well as those who are affected to get primary data. In the framework of embodying the equitable and prosperous masses based on the Pannual and the 1945 Constitution, the Government needs to carry out development for the public interest. One of the national developments is the construction of toll roads. This development requires a text based on the principles contained in the 1945 Constitution and the law of inheritance, among other principles of justice, safety, security, security, safety, security and security. The concept of general interests has been accommodated in the provisions of Law Number 2 of 2012 by defining the general interests as the interests of Nation, the State, must be manifested by the Government and its wealth. The execution of the endeavor must require a role as well as persistence to give and remove the hand with no principled loss of consensus to seek consensus. However, it turns out that the development of the Malang-Pandan toll road has caused problems and has not found a solution / way out. due to the discovery of 2 plots of land affected by development that are outside the location determination. Remembering the letter from the Head of the Department of Defense of Malang City Number: 228 / 12-35.73 / I / 2020 dated 27 January 2020 regarding the Application of Legal Studies which was sent to the Head of State Government of the State of Malang City who in essence requested to be given a legal review of the found property requested by the community.
\end{abstract}

Keywords: the procuring of land, of obstacles, of impact

DOI: $10.7176 / \mathrm{JLPG} / 104-10$

Publication date: December $31^{\text {st }} 2020$

\section{PRELIMINARY}

In order to embody the people who are just and for a long time, based on the Poetry and the Constitution of 1945 , the Government needs to carry out the development. In the efforts of the national development plan that the Government is considering, in the form of development for the public interest. This development requires a text based on the principles contained in the 1945 Constitution and the law of inheritance, among other principles of justice, mortality, legal stability, agreement, welfare, and harmony.

The government fee in national development, namely the construction of toll roads. National development for general interests like this requires a very old area and a lot of its owners. In order to meet the needs of the year, the procurement of land was carried out based on the principles in the 1945 Constitution And as contained in the State Institution of the Republic of Indonesia number 22 of 2012 Law Number 2 of 2012 Regarding the Land Development for Public Interest and its exploration is contained in the Addition of State Agency of the Republic of Indonesia number 5280 in 2012.

The authority of the state that is contained in Article 2 subsection 2 letters a of Law number 5 of 1960 regarding Basic Agrarian Principles (hereinafter referred to as UUPA) which states: "The right to control of the State referred to in paragraph (1) of this article authorizes: organize and maintain the allocation, use, preparation and maintenance of the earth, water and space ". On the basis of the public interest, the Government can take the right to land by compensating for damages that are actually based on the rules prescribed by Law. ${ }^{1}$ To control the state of the land, also to give the authority to the State to arrange the procurement of land which is allocated for development for the benefit of the nation and the country. In order to exercise the regulatory authority, land

Article of Law number 5 of 1960 regarding Basic Agrarian Principles:

Untuk kepentingan umum, termasuk kepentingan bangsa dan Negara serta kepentingan bersama dari rakyat, hak-hak atas tanah dapat dicabut, dengan memberi ganti kerugian yang layak dan menurut cara yang diatur dengan Undang-Undang. 
acquisition for the public interest in order to realize development by the State for the public interest is carried out in a way to provide a decent compensation for the loss that is obtained through deliberation, so that the public interest is granted, so that the public interest is granted. so that the dispute / problem will relatively not happen. Even if the reality in the field, matters related to land events still cause a lot of disputes ${ }^{1}$ Between the Government and the former owner, both as individuals and legal entities that are related to the project Through the Coordinating Ministry for Economic Affairs, proposes making the mechanism of managing the management system of administering infrastructure regulating the management system. Through this mechanism, the Priority Infrastructure Provider Speed Committee (KPPIP) was formed by the results of the performance conducted by the Priority Infrastructure Provider Speed Committee (KPPIP) mentioned the highest level of training performance. ${ }^{2}$ This thing causes a lot of people who refuse to use it for infrastructure development, even though there are many people who ask for a loss that is higher than the price. ${ }^{3}$ From the results of the work that has been carried out by KPPIP, information can be obtained that the problem of infrastructure development in Indonesia, that is First, the problem of planning and secondly, the problem of liberation is concerned with the management of land for the general interest.

To anticipate this problem, the concept of the general interest has been accommodated in the provisions of Law Number 2 of 2012 by defining the general interests as the interests of the Nation, the State, the people must be manifested by the Government and used by the people's wealth. The execution of the experience must require both the role and the persistence to give and remove the hand with the principle of loss of consensus to seek consensus.

Setting the development location is given a period of 2 years and can be extended for a maximum of 1 year. If in the time setting the location is not fulfilled, the process of determining the location of the time has not been completed. So complex is the planning process so that every activity in the plan must be fulfilled so that the process of executing the event is over. In the construction of toll roads carried out by the Government to obtain a landslide by using the legal rules of conviction that are in effect. The development of toll roads in Indonesia is included in the categories for the general interest even though the institution that requires a state-owned company, namely PT. Jasa Marga. ${ }^{4}$ The general interest which is implied in this matter is the one that is of utmost importance and which must be realized by the Government for the welfare of the people.

The problem of land development for the construction of the toll road has not been completed. Remembered the letter from the Head of the Ministry of Agriculture Malang City Number: 228/12-35.73/I/2020 on 27 January 2020 regarding the Request for the Judgment of the Law that was sent to Head of the State Prosecutor's Office Malang City which in essence asked to be given the title of law or what was asked by the masses. Land conditions that have occurred in the construction of the Pandaan-Malang toll road construction have not found a solution/way out.

\section{METHOD}

In writing this legal research, the author uses empirical legal research/socio-legal research. This research was carried out by means of an observation process at an institution related to the construction of the Manjang-Pandan Road Highway, especially in the MALANG City area and interviews with respondents or sources related to the problem being researched, namely Governmental Institutions as a whole related to the land for the construction of toll roads in Malang City as well as those who are affected in the region madyopuro village Kedungkandang District Malang City. This research uses a case study approach. The case study was chosen because there were problems related to land completion, which were outside the placement of location in the current experience for the construction of the Pandaan-Malang toll road for the public interest madyopuro village, Kedungkandang District, Malang City

\section{RESULTS AND DISCUSSION}

1. Analysis of the affected land outside the determination of location in land development for the construction of the Pandaan-Malang toll road in Madyopuro village, Kedungkandang District

Mohammad Ali, ${ }^{5}$ argues that development is every effort or every action that is carried out in a planned way to make changes aimed at improving, increasing the standard of life, welfare and quality of humans. The

Conflict, according to the Indonesian Head of District Court, is a dispute, a dispute, a case (in court); something that caused the difference in income, opinion contention, defense.

Hotman Sidauruk, Tanah Untuk Kepentingan Umum, selaku Kepala Bidang Perumahan dan Pertanahan Kementerian Koordinator Bidang Perekonomian dalam situs resmi KPPIP (Komite Percepatan Penyediaan Infrastruktur Prioritas), https://kppip.go.id/opini/tanah-untukkepentingan-umum/ (diakses 13 Februari 2020).

Evi Fajriantina Lova, Jurnal, Pengadaan Tanah Dalam Pembangunan Infrastruktur Jalan Tol Oleh Badan Usaha Milik Negara (Persero), Program Studi Magister Kenotariatan Fakultas Hukum Universitas Brawijaya, 2016. hlm.15.

Evi Fajriantina Lova, op.cit. hlm.17

http://pengertiandefinisi.com/pengertian-pembangunan-menurut-para-ahli/, (online),

diakses pada tanggal 06 Maret 2020. 
construction of the Pandan-Malang toll road is included in the area of a national strategic project, built over a period of more than 37.62 kilometers $(\mathrm{km})$, designed to increase connectivity in the South East Indonesia Region as the South East Region of 2018 and almost as much in Presidential Regulation Number 56 of 2018 concerning the second amendment to Presidential Regulation number 3 of 2016 concerning the Acceleration of Implementation of National Strategic Projects. ${ }^{1}$. This toll road has a route that crosses 3 (three) administrative areas, namely the Head District of Pasuruan, the Head of MALANG and MALANG City. Its existence will be connected to the existing national roads, from Pandanus then leads to the south, namely Purwosari, Purwodadi, Lawang, Singosari, Karanglo, and ends. Even though the party responsible for organizing the development, namely the Ministry of Public Works and Public Works, is more specific, that is, Organizers Toll Road. ${ }^{2}$

Even though the construction development plan has started since 2017, while the plan began to be operated in 2019. ${ }^{3}$ However, in the past, this research was carried out at the same time as the February month of 2020 the toll gate located in Madyopuro Village, the level of the Mood City, which has not been able to operate yet. According to Mr. Siswantono, ${ }^{4}$ Explaining that the liberation of training in Mádyopuro Village is difficult to achieve an agreement. For the reason that there was no agreement at no loss and the owner was reluctant to remove what he had. Apart from that, the current conditions are two months affected by the construction of the toll road, but it is outside the location determination (not included in the location setting according to the East Java Governor Decree).

It was only discovered in 2018 that the affected land outside the determination of location was at the time of toll road construction. The movement or mobilization of heavy equipment that was working at that time resulted in damage to 2 houses belonging to Suliaswati and Suliastutik. ${ }^{5}$ Then the problem arose starting from a letter dated 17 October 2020 signed by Suliastutik and a letter dated 21 October 2020 signed by Suliswati who both have the subject: a request for land acquisition for the Pandaan-Malang toll road which is addressed to the Land Procurement Committee. Then the Head of Malang City Land Acquisition Executive responded to the construction of the Pandaan-Malang Toll Road by holding a meeting (first) on Thursday, November 14, 2019 at the Grand Cakra Malang Hotel which discussed the Government's attitude in responding to land acquisition requests in Madyopuro Village. The two affected lands are outside the toll road construction land acquisition markers on behalf of the owners Suliswati and Suliastutik. From the results of the first meeting, it was agreed that there were 2 alternatives to address the problems that occurred. The first alternative was land acquisition, while the second alternative was an access road for the 2 houses whose land was affected. ${ }^{6}$ Then it was agreed by all officials present at the first meeting that the settlement of the affected land outside the penlok was completed by means of land acquisition. The meeting held by related agencies according to De Den G Pruitt and Jeffrey Z. Rubin was a way to satisfy the parties in overcoming the problem by means of problem solving (problem solving).

After obtaining a mutual agreement based on the results of the first meeting that the problems of the affected land outside the penlok were resolved by land acquisition, the PPK (Commitment Making Officer) Land Procurement for the Pandaan-Malang Toll Road, which was held by Mr. R. Agus Sulihanto, wrote an official letter to the Head of BPKP ( Finance and Development Supervisory Agency) Representative of East Java Province, which in essence requested an opinion on the land acquisition application submitted by Suliswati and Suliastutik to the Chief Executive of Land Acquisition in Malang City for the Construction of the Pandaan-Malang Toll Road.

PPK land acquisition for the construction of the Malang-Pandaan toll road carries out its duties and responsibilities for the delegation of authority from the KPA (Budget User Authority) which is given by means of a decree to take actions that result in spending the state budget at the expense of the State Revenue and Expenditure Budget (APBN) in management. The stipulation of the draft land acquisition contract must meet the requirements in the implementation of payments, it is PPK's obligation to test whether it has met the requirements or not. If PPK does not carry out its responsibilities, PPK will be subject to legal sanctions either administrative legal sanctions, criminal penalties or civil legal sanctions. PPK action by asking for consideration from BPKP Representative of East Java Province in writing by letter (official) according to F.A.M. Stroink and J.G. Steenbeek is the legal authority of a public official regarding the competence of legal actions that can be carried out according to formal principles and in accordance with the concept of state administrative law.

As for the Letter of the Head of BPKP Representative of East Java Province Number: S-7270 / PW13 / 2/2019 dated December 16, 2019 concerning Land Affected by Land Acquisition for the Pandaan-Malang Toll Road

Peraturan Presiden Nomor 56 Tahun 2018 tentang Perubahan Kedua Atas Peraturan Presiden Nomor 3 Tahun 2016 tentang Percepatan Pelaksanaan Proyek Strategis Nasional.

https://kppip.go.id/proyek-strategis-nasional/a-proyek-pembangunan-infrastruktur-jalan-tol/jalan-tol-pandaan-malang-3762km/diakses pada tanggal 07 Maret 2020.

Ibid.

Interview with Mr. Siswantono, Technical Director of PT. The Pandaan-Malang Service, on Monday 24 February 2020.

Ibid.

Interview with Mr. Dahat, Head of Spatial Planning DPUPRPKP; Mr. Erlan Sulistyono, Head of the Building and Environmental Management Section; Mr. Surya Adhi N., Head of Spatial Control Section; Mr. Dedy Indrawan, Head of the Spatial Planning Section and Mrs. Nurul, Head of the Spatial Land Affairs Section on Tuesday, May 5, 2020. 
addressed to the PPK Land Procurement for the Pandaan-Malang Toll Road, which in essence has the following opinion :

1. A land acquisition applicant by 2 residents of Madyopuro Village, Kedungkandang Subdistrict, Malang City on behalf of Suliswati (land area 107m2) and Suliastutik (land area $97 \mathrm{~m} 2$ ) can be considered to be fulfilled by first being verified by the Land Procurement Implementer.

2. In terms of verification can be carried out, the Land Acquisition Implementer must consider the fulfillment criteria and conditions in the field, as follows:

a. Verification must be able to determine the fulfillment of the criteria that the land parcel is no longer able to function according to its designation and use, so that it is feasible to be released by obtaining compensation.

b. Social impacts, namely the existence of similar claims that could potentially occur in the area closest to the Pandaan-Malang toll road as well as on other toll roads as a result of land acquisition outside the ROW because it can be categorized as "affected communities" (Article 19 paragraph (2) Law Number 2 of 2012).

c. The field conditions of the two land parcels are, whether the construction of the Pandaan-Malang toll road really does not have an access road so that it is isolated, as stated by the owner of the two land parcels.

d. Considering the benefits of the acquired land parcels for the benefit of the community and the state.

3. Re-evaluate the initial plan and obligations of the Toll Road Regulatory Agency (BPJT) to the locations of buildings and people's land along the Pandaan-Malang toll road that are not freed (not included in the blocking), related to the construction of a replacement road to provide access roads for residents affected by toll road construction. Including whether there is a plan to build a replacement road to provide access for the two land parcels requesting release to the nearest neighborhood.

4. Land acquisition must be able to have a positive impact on the wider community, taking into account the feeling of fairness for the affected communities in the implementation of land acquisition / release for the public interest.

Then on Tuesday, January 14, 2020 at the PT. Jasamarga

Pandaan-Malang in Singosari a second meeting was held to discuss the 2 affected lands that were outside the determination of the location. The discussion of the meeting basically discussed a letter from the Head of BPKP Representative of East Java Province Number: S-7270 / PW13 / 2/2019 dated December 16, 2019 regarding Land Affected by Land Procurement for the Pandaan-Malang Toll Road. The meeting was attended by Malang City ATR / BPN Officials, Pandaan-Malang Toll Road PPK Officials, Malang City Social Service Officials, Malang City DLH Officials, Kedungkandang Sub-District Heads, Malang City Public Prosecutors Officers, Malang Police Members, PT. JPM, Malang City DPUPRPKP, Madyopuro Urban Village Head with the conclusion of the meeting that in order to acquire land on the two lands affected by the toll road construction, technical recommendations are still needed:

1. DPUPRPKP of Malang City (Department of General Work, Area Administration, Housing and Settlement Areas of Malang City) recommendations related to the assessment of building disabilities.

2. Dinsos P3AP2KB Malang City (Social Affairs, Women Empowerment, Child Protection, Population Control and Family Planning Malang City) recommendations related to social performance.

3. The Malang City District Attorney's Office (Malang City Prosecutor's Office) and the Malang City Police (Polresta Malang) recommend a legal review.

4. PT. PANDAN-MALANG (PT. JPM) technical studies related to cost comparisons between access roads along with construction with estimated price and builds.

Meanwhile, according to Mr Sulam Samsul and Mr Amir Abdul Hakim on technical recommendations from 5 agencies, namely DPUPR Malang City; Social Affairs P3AP2KB; MALANG CITY STATE AGENCY; The City Police and PT. JPM in accordance with the results of the first meeting had agreed and wanted one vote, namely by way of land acquisition in Madyopuro Village, Kedungkandang District, Malang City. One vote that was meant was a recommendation from 5 related agencies to jointly acquire 2 affected land parcels that were outside the location determination.

The condition of the 2 affected lands which are outside the determination of the location of land acquisition for the construction of the Pandaan-Malang toll road in Madyopuro Village cannot be resolved legally because according to Mr. Sulam Samsul, A.Ptnh. and Mr. Amir Abdul Hakim, S.H., M.M., ${ }^{1}$ still waiting for a recommendation from the Malang Police regarding a legal review of the settlement of the affected land. Requests for a legal review from the Police tend to avoid potential state financial losses due to land acquisition on 2 affected lands outside of the land office. ${ }^{2}$ As for the condition of the 2 plots of land on which there are buildings in the form

Interview with Mr. Sulam Samsul, A.Ptnh., Head of Malang City ATR / BPN Land Office, Chief Executive of Land Acquisition for the Development of the Pandaan-Malang Toll Road, Malang City; Mr. Amir Abdul Hakim, S.H., M.M., Head of the Land Acquisition Section on Tuesday, May 05, 2020.

Ibid. 
of houses belonging to Suliswati and Suliastutik, the condition is currently damaged because in the implementation of toll road construction in the area it is affected / the effect of the mobilization and operation of heavy equipment. ${ }^{1}$

There are those outside the setting of the location to be better control in managing the development of the Pandaan-Malang toll road and also in the management of public management. The presence of 2 landlords is located near the Madyopuro toll gate. While at location 2 years there were those seen according to the Technical Director of PT. JPM, ${ }^{2}$ in the future there will be public facilities for toll road operations because it is very strategic, which is near the Madyopuro toll gate.

That the Establishment of the Development Location for the Toll Road or the Approval Letter for the Establishment of the Development Location (SP2LP) for the Pandaan-Malang Toll Road is the determination of the location of the development determined by the Governor's Decree which is used as a permit to endowments, land use changes, and health care as well as related to the State Institution of the Republic of Indonesia Number 55 of 2015. ${ }^{3}$ Based on the Location of Location (Penlok), the development of the Pandaan-Malang toll road route which was set through East Java Governor's Decree Number: 188/282 / KPTS / 013/2011 dated June 7, 2011 and has already changed the length of time and the disposal, the last letter was the Governor of East Java's Decree Number: 188/244 / KPTS / 013/2019 dated May 24, 2019.

In accordance with the provisions of Article 24 and Article 25 of the Supreme Court Regulation of the Republic of Indonesia Number 3 of 2016 concerning Procedures for Filing Objections and Custody of Compensation to the District Court in Land Procurement for Development for Public Interest states that the requirements that must be met by agencies requiring land in terms of compensation losses are made through a consignment or custody of compensation at a District Court located in the local jurisdiction. In accordance with the provisions of Article 24 and Article 25 of the Regulation of the Supreme Court of the Republic of Indonesia Number 3 Tah One of the requirements for custody of compensation based on the provisions of Article 25 paragraph (1) letter c number 3 of this Perma, namely the description on which the application for custody of compensation includes a complete and clear mention. Decree of the Governor, Regent / Mayor regarding the determination of the location of the construction and based on the provisions of Article 25 paragraph (2) letter b, namely the application for deposit of compensation, attached with supporting documents in the form of a photocopy of the Governor's Decree or the Regent / Mayor's Decree regarding the determination of the construction location for the public interest indicating the application as Agencies requiring land.un 2016 concerning Procedures for Submitting Objections and Custody of Compensation to the District Court in Land Procurement for Development for Public Interest states that the requirements that must be met by agencies requiring land in terms of compensation are made through consignment or custody of compensation at the District Court located in the local jurisdiction. It is very clear in the provisions of this Article that to fulfill the requirements for the deposit of compensation, it is necessary to determine the location determined by the Governor or Regent / Mayor through a decree. That in the absence of a location determination in land acquisition, the construction of the PandaanMalang toll road is located on 2 lands belonging to Siliastutik and Suliswati resulting in 2 plots of land belonging to Suliswati and Suliastutik which are outside the location determination that land acquisition cannot be carried out by providing compensation for the consequences of land acquisition for development for public interests. According to Philipus M.Hadjon, the aspect of authority requires that every act / action of the government must be based on legitimate authority, in this case the Location Determination, if a disability occurs, it can cause a defect in authority (onbevoegdheid). ${ }^{4}$

From the opinions of the experts above, the researcher wants to use the opinions of the experts above as a basic concept in researching and finally finding the facts that cause problems in making land acquisition plans for the construction of the Malang-Pandaan toll road, especially for affected land outside the location determination. And factors inhibiting the completion of land acquisition on affected land.

\section{Case Mapping}

According to the Big Indonesian Dictionary (KBBI), the definition of dispute is something that causes differences of opinion to dispute. Meanwhile, Chomzah (2003: 14) states, ${ }^{5}$ that a dispute is a conflict between two or more parties that originates from different perceptions of an interest or property rights that can have legal consequences for both. There are several types of dispute resolution methods, namely courts and alternative dispute resolution

Op.Cit. hlm.30 dan Op.Cit. hlm.26.

Op.cit. hlm.26.

Peraturan Presiden Nomor 30 Tahun 2015 tentang Perubahan Ketiga Atas Peraturan Presiden Nomor 71 Tahun 2012 Tentang Penyelenggaraan Pengadaan Tanah Bagi Pembangunan Untuk Kepentingan Umum.

$4 \quad$ Philipus Mandiri Hadjon, Fungsi Normatif Hukum Administrasi Dalam Mewujudkan Pemerintahan Yang Bersih, Orasi Ilmiah Pengukuhan Jabatan Guru Besar Dalam Ilmu Hukum, Fakultas Hukum Universitas Airlangga, Surabaya, 10 oktober 1994, hlm.7.

Muchlisin Riadi, (online), Pengertian, Jenis, Penyebab dan Penyelesaian Sengketa, https://www.kajianpustaka.com/2018/10/pengertianjenis-penyebab-dan-penyelesaian-

sengketa.html\#: :text=Menurut $\% 20$ Amriani $\% 20(2012 \% 3 \mathrm{~A} 12)$,apa $\% 20$ yang $\% 20$ dinamakan $\% 20$ dengan $\% 20$ sengketa., diupload tanggal 23 Oktober 2018, diakses tanggal 11 Agustus 2020 
(APS) outside the court. APS types include negotiation and mediation. Negotiation is a way to find solutions to problems through deliberation carried out directly between the parties (Article 1 number 3 of Law Number 30 of 1999 concerning Arbitration and Alternative Dispute Resolution, "Parties are legal subjects, both according to civil law and public law") disputing parties whose results will be accepted by the parties. Based on Law Number 30 of 1999, that ADR (alternative dispute resolution) or APS (alternative dispute resolution) is a dispute resolution institution or difference of opinion through a procedure agreed by the parties, namely settlement outside the court by means of consultation, negotiation, mediation, conciliation, or expert judgment.

In this study, ADR / APS (non-litigation) is prioritized to find the best solution (win win solution) for the affected land problems outside the determination of the location of land acquisition for toll road construction in Madyopuro Village, Kedungkandang District, Malang City, rather than litigation settlement (through the Court ) which positions the parties against each other. Dispute resolution through the Court is a final means (ultimum remidium) if it is deemed that non-litigation dispute resolution is not successful.

The problem of land acquisition for development in the public interest of the affected land outside the location determination which is in Madyopuro Village, Kedungkandang District, Malang City can be mapped into 2 things, namely juridical problems and technical (nonyuridis) problems.

\section{Juridical Issues}

According to Philipus M. Hadjon, the validity of an act of government is based on aspects of authority, procedure and substance, as follows: ${ }^{1}$

1. Aspects of authority, limited by: a. Theory;

$$
\begin{aligned}
& \text { b. Territory; and } \\
& \text { c. Time }
\end{aligned}
$$

If there is a defect in the above aspects, then there is a defect in authority (onbevoegdheid).

2. Procedure aspects, based on:

a. The principle of rule of law: The principle of rule of law is closely related to the protection of basic human rights

b. Principles of Democracy: closely related to the principle of openness in government administration

c. Instrumental principle: consists of the principle of efficiency and the principle of effectiveness.

3. Substantial aspect: the Government's authority is substantially limited by "what" and "for what".

a. "What" flaw: an arbitrary Government action

b. Flaw "for what": Government acts of abuse of power.

The following describes the juridical problems that occurred in the field with regard to the authority of the Government:

1. Less Optimal Initial Planning for Toll Road Development.

2. Agreement of Related Agencies for Land Acquisition of Affected Lands Outside the Determination of Location.

\section{a. Technical / Nonyuridical Problems}

Whereas when this research was conducted, there were non-juridical / technical findings in the field, including:

1. There is no access road for the two affected houses;

2. The construction of two houses whose land is affected is damaged;

3. Affected land affects the safety of toll road land.

\section{b. Barriers to Settlement of Affected Land}

Before analyzing the settlement of land acquisition on affected land outside of the location determination, in analyzing the obstacles in settling the affected land outside the location determination, the obstacle factors in this sub-chapter are divided into 2, namely: juridical factors and technical / non-juridical factors.

\section{Juridical Barriers}

As for the juridical inhibiting factors that were found, among others:

1. Request for a legal review to the Malang City Police;

Regarding the problem of affected land outside the penlok located in Madyopuro Village, Kedungkandang District, Malang City, the National Police cq. Malang City Police do not have the authority to solve problems. The absence of elements of criminal acts, both violations and crimes, in the elements of the affected land issue outside the land office that violate the criminal provisions in the prevailing laws and regulations make the Police unable to provide a legal review regarding land acquisition which is the settlement of affected land in Madyopuro. According to Philipus M. Hadjon, the aspect of authority possessed by the Police is based on Law Number 2 of 2002, so that every action / action of the National Police must be based on the legitimate authority that exists in the provisions of the laws and regulations concerning Polri. If the National Police provides legal considerations related to land

Philipus Mandiri Hadjon, Fungsi Normatif Hukum Administrasi Dalam Mewujudkan Pemerintahan Yang Bersih, Orasi Ilmiah Pengukuhan Jabatan Guru Besar Dalam Ilmu Hukum, Fakultas Hukum Universitas Airlangga, Surabaya, 10 oktober 1994, hlm.7. 
acquisition in order to resolve the problem of affected land outside of the local government, it will result in a defect in authority (onbevoegdheid). ${ }^{1}$

2. Potential losses to state finances;

According to the Chief Executive of Land Acquisition for the Development of the Pandaan-Malang Toll Road, Malang City, ${ }^{2}$ hat the involvement of elements from the Attorney General's Office and the Police in the meeting to resolve the affected land issues outside the location determination is to anticipate potential state losses so that they are not subject to criminal charges as threatened in Article 2 and Article 3 of Law Number 31 of 1999 concerning Eradication of Corruption Crimes in conjunction with Law Number 20 of 2001 concerning Amendments to Law Number 31 of 1999 concerning Eradication of Corruption Crimes. Given the source of funds in the implementation of land acquisition for the construction of the Malang-Pandaan toll road using the APBN. 3. Legal Opinion from State Attorney Attorney at Malang City District Attorney

Whereas the Head of the Malang City ATR / BPN Land Office who also serves as the Chief Executive of the Land Procurement for the Development of the Pandaan-Malang Toll Road, Malang City, wrote to the Head of Malang City Public Prosecutor through letter Number: 228 / 12-35.73 / I / 2020 dated January 27, 2020 regarding application for legal review, which in essence requests for a legal review as a consideration in deciding whether or not the application for land acquisition of the affected land is appropriate outside of the location determination belonging to Suliastutik and Suliaswati which is in Madyopuro Village, Kedungkandang District, Malang City. Then the letter was answered through the Legal Opinion (S-6) by the State Attorney at the Malang City State Prosecutor's Office on March 5, 2020 with the conclusion that the affected land which is outside the designation can be done by submitting a new location determination to the Governor based on the minutes of the agreement on during the public consultation or re-public consultation. On the juridical recommendation from the JPN, the Chief Executive of Land Acquisition can carry out the legal opinion or not.

\section{Technical / Nonyuridical Barriers}

Whereas in addition to the juridical obstacles described above, there are also technical obstacles. The technical / nonuridical obstacles are as follows:

\section{a. Malang City DPUPRPKP has not conducted a technical study}

According to Mr. Dahat, ${ }^{3}$ as Head of Spatial Planning DPUPRPKP Malang City who was met and interviewed by Researchers at the Malang City DPUPRPKP Office on Tuesday, May 05, 2020 it was explained that the first meeting held on November 14, 2019 discussed the Government's attitude in responding to existing land acquisition requests in Kelurahan Madyopuro on 2 affected lands outside the land acquisition markers for toll road construction on behalf of the owners Suliswati and Suliastutik. From the results of the first meeting, it was agreed that there were 2 alternatives to address the problems that occurred. The first alternative is land acquisition, while the second alternative is building an access road. Then a second meeting was held, but according to the statement from Mr. Dahat, who attended the second meeting on January 14, 2020, Mr. Didik, this was in accordance with the attendance list on the minutes of the meeting on that date, which was later in the same month, January In 2020 Mr. Didik as the Head of the PBL (Head of the Building and Environmental Arrangement Section) DPUPRPKP Malang City has retired, but the conditions in the PUPRPKP Office of Malang City have missed communication, namely the replacement official, Mr. Erlan Sulistyono, was not informed of the existing reports regarding the second meeting dated January 14, 2020. So that the Malang City DPUPRPKP has not taken a stance to provide technical recommendations based on the results of the second meeting dated January 14, 2020 and the condition of Malang City DPUPRPKP has also not received the Minutes of Hasil Rates of the Discussion of the Lands in which the Development of Road Toll Road is clear, January 14, 2020. Mr. Erlan Sulistyono as Head of the PBL (Head of the Section of Building and Environmental Management) DPUPRPKP Malang City has not implemented what was the result of the second meeting and at the time of the interview the researcher provided a photocopy of the file of the Minutes of Hasil Rapat Deliberation, The Includes Devel- opment Toll Road 14 Januari 2020 to be able to assist the duties of the PUPRPKP Office of Malang City in addressing the problems of affected land outside the determination of the location in Madyopuro Village and accelerating the process for Malang City DPUPRPKP to provide technical recommendations regarding the feasibility of buildings based on the results the second meeting on January 14, 2020 to the Land Acquisition Implementer and was responded positively by officials in the Malang City DPUPRPKP environment because this research was very helpful for the Malang City DPUPRPKP. The next condition, related to the application letter from the Implementer of Land Procurement for the Construction of the Pandaan-Malang Toll Road, chaired by the Head of the Malang City ATR / BPN Land Office addressed to the

Philipus Mandiri Hadjon, Fungsi Normatif Hukum Administrasi Dalam Mewujudkan Pemerintahan Yang Bersih, Orasi Ilmiah Pengukuhan Jabatan Guru Besar Dalam Ilmu Hukum, Fakultas Hukum Universitas Airlangga, Surabaya, 10 oktober 1994, hlm.7.

Interview with Mr. Sulam Samsul, A.Ptnh., Head of Malang City ATR / BPN Land Office, Chief Executive of Land Acquisition for the Development of the Pandaan-Malang Toll Road, Malang City; Mr. Amir Abdul Hakim, S.H., M.M., Head of the Land Acquisition Section on Tuesday, May 05, 2020

Interview, tuesday, 05 May 2020 di Kantor Dinas PUPRPKP Kota Malang. 
PUPRPKP Office of Malang City, its existence is still being sought so that this adds to the long performance of the Malang City PUPRPKP Office in provide a stance regarding technical recommendations regarding the feasibility of a building based on the results of the second meeting on January 14, 2020 for the completion of land acquisition on 2 affected land parcels outside the penlok where each residential house is located.

\section{b. Malang City P3AP2KB Social Agency has not conducted a technical study}

On Monday, May 4, 2020, an interview was conducted with Ms. Penny Indriani as Head of the Social Service, Women's Empowerment, Child Protection, Population Control and Family Planning (Social Service, P3AP2KB) Malang City, ${ }^{1}$ explained by Ms. Penny that as Head of the Social Service, P3AP2KB Malang City has not received a letter of request from the Implementer of Land Procurement for the Construction of the Pandaan-Malang Toll Road, Malang City regarding technical recommendations made by the Social Service, P3AP2KB of Malang City regarding a social impact study on the problem of 2 affected lands outside of the markers belonging to Suliastutik and Suliswati who are located in Madyopuro Village, Kedungkandang District, Malang City. According to the Malang City Head of Social Affairs, the official who was present at the second meeting on January 14, 2020 at that time was Mr. Edy Sukiswo as the official representing the Social Service, P3AP2KB Malang City, this was in accordance with the attendance list at the meeting. However, when the interview was conducted, information was obtained that Mr. Edy Sukiswo had passed away, while the report from Mr. Edy Sukiswo had not yet reached Ms. Penny as the Head of Social Service, P3AP2KB Malang City. In this case at the Social Service, P3AP2KB Malang City, there was a miss communication which resulted in a social impact study related to 2 affected land parcels outside the penlok in the Madyopuro area according to the results of the second meeting on January 14, 2020, which could not be given to the Malang City Land Acquisition Organizer.

In addition, according to her statement, Ms. Penny herself just served as Head of the Malang City Social Service, P3AP2KB in January 2020, previously Mrs. Penny served as Head of the Office of Women's Empowerment, Child Protection, Population Control and Family Planning. In the service structure there is a merger of two agencies, namely the Social Service with the Office for Women Empowerment, Child Protection, Population Control and Family Planning based on Malang City Regional Regulation Number 5 of 2019 concerning Amendments to Malang City Regional Regulation Number 7 of 2016 concerning the Formation and Composition of Equipment Area. This has resulted in all matters previously handled by the Malang City Social Service including the problem of resolving 2 affected land parcels outside the penlok on which there is a building in the form of a residence which is unknown to Ms. Penny, who is currently the Head of the Social Service, P3AP2KB Malang City.

${ }^{21}$ which states that the authority or merger of two services into one service is obtained by contribution, namely the granting of new government authority by a certain point in the legislative regulations set forth in this case, Malang City Regulation No. 5 of 2019. which then proceeded to delegation of authority and there was the transfer of an authority that has been carried out by the Social Service, P3AP2KB Malang City which has obtained an attributive authority of the government.

The adjustment of duties and functions of the merger of the two agencies does take time, but as stated by Philip M. Hadjon ${ }^{2}$ which states that the authority or merger of two services into one service is obtained by contribution, namely the granting of new government authority by a certain point in the legislative regulations set forth in this case, Malang City Regulation No. 5 of 2019. which then proceeded to delegation of authority and there was the transfer of an authority that has been carried out by the Social Service, P3AP2KB Malang City which has obtained an attributive authority of the government.

The These things have caused the slow settlement of the two affected lands outside the determination of the location of land acquisition in Madyopuro Village, Kedungkandang District, Malang City.

The condition of the merger of two agencies into one between the Malang City P3AP2KB Office and the Malang City Social Service as a consequence of the Malang City Regulation Number 5 of 2019 concerning Amendments to Regional Regulation Number 7 of 2016 is basically the authority of the Malang City Government in this case the Mayor of Malang City is based on the principle efficiency, effectiveness, division of tasks, span of control, clear work procedures, flexibility, government affairs that become regional authorities, and intensity of government affairs and regional potential in Malang City. The formation of Regional Apparatus is basically the existence of Governmental affairs that are delegated to the regions, consisting of Government affairs which are mandatory in nature and Government affairs which are optional in nature. Government affairs that are obligatory in nature are divided into Government affairs related to basic services and those that are not. The formation of a regional apparatus takes into account the factors of the size of the area, the size of the population, the financial capacity of the area and the responsibility of assignment to the region as a mandate that must be carried out by each region through the regional apparatus. As stated by Indroharto adjustment of duties and functions of the

Interview monday 04 May 2020 di Kantor Dinas Sosial, Pemberdayaan Perempuan, Perlindungan Anak, Pengendalian Penduduk dan Keluarga Berencana (Dinas Sosial, P3AP2KB) Kota Malang.

Indroharto. “Usaha Memahami Undang-undang tentang Peradilan Tata Usaha Negara”.Pustaka Harapan, Jakarta. 1993. hal.68. 
merger of the two agencies does take time, but as stated by Philip M. Hadjon, ${ }^{1}$ the aspect of authority requires that every action of the Government must be based on legitimate authority so that the extent of the authority of the Social Service, P3AP2KB of Malang City has become an obligation that cannot be avoided even though in new conditions there is a merger but the authority remains inherent and legitimate so that the Social Service, City P3AP2KB Malang must carry out everything that is its obligation according to its authority, including in providing technical recommendations regarding the social impacts that occur on 2 affected land plots outside the existing location determination in Madyopuro Village, Kedungkandang District, Malang City.

\section{CONCLUSION}

Analysis of the affected land outside the determination of location in land development for the construction of the Pandaan-Malang toll road in Madyopuro Sub-district, Kedungkan District. This study uses the opinions of experts as a basic concept in researching and finally finding the causes of problems in making land acquisition plans for the construction of the Malang-Pandaan toll road, especially for affected land outside the location determination. Problems and barriers to land acquisition for development in the public interest of affected land outside of the determination of the location in Madyopuro Village, Kedungkandang District, Malang City can be mapped into 2 things, namely juridical problems and technical (nonyuridis) problems.

The juridical problems that occur in the field due to this research are related to the authority of the Government: a. Less Optimal Initial Planning for Toll Road Development.

b. Agreement of Related Agencies for Land Acquisition of Affected Lands Outside the Determination of Location. Technical / Nonyuridical Problems, Whereas when this research was conducted, in the field there were nonuridical / technical findings, including:

1. There is no access road for the two affected houses;

2. The construction of two houses whose land is affected is damaged;

3. Affected land affects the safety of toll road land.

The juridical inhibiting factors that were found included:

1. Request for a legal review to the Malang City Police;

2. Potential losses to state finances;

3. Legal Opinion from State Attorney Attorney at Malang City District Attorney

Technical / Non-Juridical Barriers, Whereas apart from the juridical obstacles described above, there are also technical obstacles. The technical / nonuridical obstacles are as follows:

1. Malang City DPUPRPKP has not conducted a technical study;

2. The Department of Social Affairs P3AP2KB Malang City has not conducted a technical study;

\section{BIBLIOGRAPHY}

BOOK :

A.P. Parlindungan,Komentar Atas Undang-Undang Pokok Agrarian,Bandung: Mandar Maju, 1991.

, Landreform di Indonesia, Ujung Pandang :Bahan Literatur Mahasiswa API dan STIKI, 1983.

A. Ridwan Halim, Hukum Agraria Dalam Tanya Jawab, Jakarta: Balai Aksara, Yudhistira, Pustaka Saadiyah, 1985.

Abdul Ghofur Anshori dan Shobirin Malian, Membangun Hukum Indonesia, Yogyakarta: Kreasi Total Media, 2008

Achmad Ali, Menguak Teori Hukum (Legal Theory) dan Teori peradilan (Judicialprudence)Termasuk Interpretasi Undang-Undang (Legisprudence),Jakarta: Prenada Media Group, 2009.

Achmad Rubaie, Hukum Pengadaan Tanah Untuk Kepentingan Umum, Malang: Bayumedia Publishing, 2007. Achmad Sodiki, Politik Hukum Agraria, Jakarta: Konstitusi Press, 2013.

Adrian Sutedi, Implementasi Prinsip Kepentingan Umum Dalam Pengadaan tanah Untuk Pembangunan,Jakarta: Sinar Grafika, 2007.

Adrian Sutedi, Peralihan Hak Atas Tanah Dan Pendaftrarannya, Jakarta: Sinar Grafika, Cetakan V, 2013.

Ali Achmad Chomzah, Hukum Agraria (Pertanahan Indonesia), Jakarta: Prestasi Pustaka Karya, 2004

Ali Achmad Chomzah, Hukum Pertanahan, Jakarta : Prestasi Pustaka, 2002.

Andi Hamzah, Kamus Hukum, Jakarta:Ghalia Indonesia, 1986.

Andre Ata Ujan, Keadilan dan Demokrasi, Telaah Filsafat Politik John Rawls, Cetakan ke-5, Yogyakarta : Kanisius, 2005

Arie S. Hutagalung, Tebaran Pemikiran Seputar Masalah Hukum Tanah, Jakarta : Lembaga Pemberdayaan Hukum Indonesia, 2005.

Ariestoteles, Nicomachen Ethic, Terjemahan oleh Terence Erwin, Indianapolis: Hacket Publishing, 1985.

Philipus Mandiri Hadjon, Fungsi Normatif Hukum Administrasi Dalam Mewujudkan Pemerintahan Yang Bersih, Orasi Ilmiah Pengukuhan Jabatan Guru Besar Dalam Ilmu Hukum, Fakultas Hukum Universitas Airlangga, Surabaya, 10 oktober 1994, hlm.7. 
Arthur P.Crabtree, You And The Law, Chapter VI, Jakarta : Gramedia Pustaka, 2000.

Indroharto, Usaha Memahami Undang-Undang Tentang Peradilan Tata Usaha Negara, Jakarta : Pustaka Harapan, 1993.

\section{Jurnal}

Evi Fajriantina Lova, Pengadaan Tanah Dalam Pembangunan Infrastruktur Jalan Tol Oleh Badan Usaha Milik Negara (Persero), Program Studi Magister Kenotariatan Fakultas Hukum Universitas Brawijaya, 2016.

\section{WEBSITE}

Hotman Sidauruk, Tanah Untuk Kepentingan Umum, selaku Kepala Bidang Perumahan dan Pertanahan Kementerian Koordinator Bidang Perekonomian dalam situs resmi Komite Percepatan Penyediaan Infrastruktur Prioritas (KPPIP),https://kppip.go.id/opini/tanah-untuk-kepentingan-umum/(diakses 13 Februari 2020)

https://kppip.go.id/berita/percepatan-pembangunan-infrastruktur-untuk-menyambut-indonesia-maju-2024/

(diakses pada tanggal 06 Februari 2020)

https://humas.polri.go.id/profil/tugas-fungsi/(diakses pada tanggal 04 Mei 2020)

\section{PERATURAN PERUNDANG-UNDANGAN}

Pancasila

Undang-Undang Dasar

Undang-Undang Dasar Negara Republik IndonesiaTahun 1945.

Undang-Undang

1. $\quad$ Undang Undang Nomor 5 Tahun 1960 Tentang Pokok-Pokok Agraria;

2. $\quad$ Undang Undang Nomor 30 Tahun 2014 tentang Administrasi Pemerintahan;

3. Pasal 9 ayat (2) Undang Undang Nomor 38 Tahun 2004 tentang Jalan;

4. Undang Undang Nomor 26 Tahun 2007 tentang Penataan Ruang;

5. Undang Undang Nomor 2 Tahun 2012 tentang pengadaan tanah untuk kepentingan umum;

Peraturan Pemerintah

1. Peraturan Pemerintah Nomor 15 Tahun 2005 tentang Jalan Tol sebagaimana telah diubah terakhir dengan Peraturan Pemerintah Nomor 30 Tahun 2017

\section{Peraturan Presiden}

1. Peraturan Presiden Nomor 71 Tahun 2012 tentang Penyelenggaraan Pengadaan Tanah Bagi Pembangunan untuk Kepentingan Umum sebagaimana telah diubah terakhir dengan Peraturan Presiden Nomor 148 Tahun 2015 tentang Perubahan Keempat atas Peraturan Presiden Nomor 71 Tahun 2012 tentang Penyelenggaraan Pengadaan Tanah Bagi Pembangunan untuk Kepentingan Umum.

2. Peraturan Presiden Nomor 62 Tahun 2018 tentang Penanganan dampak Sosial Kemasyarakatan Dalam Rangka Penyediaan Tanah Untuk Pembangunan Nasional.

Peraturan Menteri

1. Peraturan Kepala Badan Pertanahan Nasional Nomor 5 Tahun 2012 Tentang Petunjuk Teknis Pengadaan Tanah;

2. Peraturan Menteri Agraria dan Tata Ruang/Kepala Badan Pertanahan Nasional Nomor 6 Tahun 2015 tentang Perubahan Atas Peraturan Kepala Badan Pertanahan Nasional Nomor 5 Tahun 2012 Tentang Petunjuk Teknis Pengadaan Tanah.

Peraturan Daerah

1. Peraturan Daerah Kota Malang Nomor 4 Tahun 2016 tentang Rencana Detail Tata Ruang Dan Peraturan Zonasi Bagian Wilayah Perkotaan Malang Timur Tahun 2016-2036. 